\title{
A Data Analytics Study on Building Characteristics Impacting Energy Consumption in Single-Family Attached Homes
}

\author{
Juan D. Gomez, Afamia Elnakat, Marzieh Jafary, Martha Wright \\ Texas Sustainable Energy Research Institute, The University of Texas at San Antonio, San Antonio, TX, USA \\ Email: Juan.Gomez@utsa.edu
}

How to cite this paper: Gomez, J.D., Elnakat, A., Jafary, M. and Wright, M. (2016) A Data Analytics Study on Building Characteristics Impacting Energy Consumption in Single-Family Attached Homes. Open Journal of Energy Efficiency, 5, 121-134. http://dx.doi.org/10.4236/ojee.2016.54011

Received: October 19, 2016

Accepted: November 29, 2016

Published: December 2, 2016

Copyright $\odot 2016$ by authors and Scientific Research Publishing Inc. This work is licensed under the Creative Commons Attribution International License (CC BY 4.0).

http://creativecommons.org/licenses/by/4.0/

\begin{abstract}
San Antonio, Texas is the seventh largest city in the United States with a population of 1.4 million people, and ranked among the fastest growing cities. To assess the implications of past and present building practices within the residential sector on future energy consumption, the energy utilization of single-family attached homes (SFAH) in Bexar County, Texas is studied. The available dataset includes $3932 \mathrm{SFAH}$ records representing about $33 \%$ of the total number of SFAHs within the county. The study is based on pairing and analyzing data at the individual building level from a variety of sources including the buildings' physical characteristics, access to fuels, and monthly energy consumption. The results indicate that the area of conditioned space, presence of swimming pools, number of stories, presence of fireplaces, fueltype, and number of shared walls are a significant factor on the energy consumption of single-family attached homes. In terms of energy consumption, all-electric twostory homes sharing two walls are the most energy efficient among SFAHs. This study can aid comprehensive master planning efforts for developing sustainable communities by highlighting key features of SFAHs and making the case for higher density housing as a viable and more energy efficient alternative to single-family detached homes (SFDH).
\end{abstract}

\section{Keywords}

Energy Efficiency, Single-Family Attached Homes, Residential Energy Consumption, Building Characteristics, Reference Buildings

\section{Introduction}

The objective of this study is to better understand the stock of single-family attached 
homes (SFAH) and associated energy utilization patterns within Bexar County, Texas. A secondary objective is to identify potential implications of current building practices and promote development of more energy-efficient housing alternatives. Pitt [1] studied energy use and greenhouse gas (GHG) emission savings from compact housing. He focused on the impact of sprawl on residential energy use, specifically the opportunity to reduce energy consumption and GHG emissions by emphasizing attached homes and multi-family structures for future residential development rather than more energy-consuming, single-family detached homes (SFDHs). Ewing \& Fang [2] in their study on the impact of urban form on US residential energy use also suggested that one way to conserve energy and minimize GHGs is to shift from single-family detached to attached homes. From an architectural standpoint townhouses are individual houses that are built side-by-side, where one or two walls of each house are shared between adjacent homes. Development of attached homes is based on a dense planning pattern with narrow-front and long footprint, which creates sustainable communities by offering higher density housing [3]. Condominiums are typically multifamily construction resembling one or more apartment or townhouse buildings. The major difference between condominiums and townhomes are the type of ownership. In contrast to condominiums in which each homebuyer acquires ownership of an individual unit including the airspace within the walls, each townhome has its own roof, as well as the ground underneath that unit [4].

In a study on the energy efficiency of townhomes, Zoeller et al. [5] investigated various housing patterns that can affect energy utilization. Researchers stated that townhomes, as the traditional housing type of New England, could improve energy efficiency due to low ratio of façade to floor area, where façade is a proxy for thermal area. Despite the fact that townhouses are a building typology rooted in earlier centuries, many of their attributes resemble single-family houses and thus make them relevant to current time [3]. In a similar study [6] the effect of housing density on energy efficiency of buildings considering the hot climatic conditions is investigated. The examined row houses configuration offered a reduction in average energy consumption that reaches $28 \%$ compared to the rest of examined residential buildings types located in urban situation. On the other hand, bigger houses require more energy than smaller houses because there is more space to heat and cool, and detached houses require more energy than attached houses of the same size due to increased exposed surface area [2].

The energy consumption of homes in cold climates is mostly heating driven while the energy consumption of homes in hot and humid climates, like that of Bexar County, Texas, is mostly cooling driven. Philipsen [7] studied the energy footprint of apartments, row houses and freestanding houses specifically in cold climates. The study looked at some proxies for heating energy consumption such as the exterior surfaces, namely the exterior walls and the roof. The study concluded that in a condition with all other things being equal (window quality, R-value of the walls, R-value of the roof), the row house would be more than twice as efficient for heating as the freestanding house, 
and the apartment again twice as efficient as the row house [7]. Bexar County, Texas has witnessed an 8.2\% increase in population from April 1, 2010 to July 1, 2014 [8], and local building practices rely on construction of SFDHs as the preferred housing alternative. Since downtown revitalization efforts started in 2010, the city has slowly shifted to a more balanced approach in which apartments and condominiums are being built in and around the city core while SFDHs are mostly built in the suburbs where land is still available.

A study focusing on energy consumption of SFAHs or townhomes will help to better understand the energy utilization patterns of this type of residential building to be considered in city planning. Ewing and Rong [2] in their study on urban form and housing stock stated that people's choice of house type is strongly related to urban form. The odds that a household will live in multifamily housing are seven times greater for compact counties. Households in multifamily housing units, characterized by shared walls and typically smaller floor space, consume less energy for space heating, cooling, and all other purposes than do households in detached single-family homes, when controlling for the age of housing structures as a proxy of construction technology [9]. Kaza [10] studied the factors that affect energy consumption within the residential building stock of a given geographic area and found that size and type are key contributing factors for energy consumption associated with conditioning of living space. In a study analyzing monthly household energy consumption among single-family residences in Texas in 2010 [11] researchers indicate that there is a significant opportunity to reduce household energy consumption by targeting specific types of households within the studied service area because many households are renter-occupied (10\%), without central cooling (18\%), and have pools (7\%). Therefore, the impact of presence of pools on the energy consumption is further studied.

The authors of this manuscript have studied over the past five years the housing stock within the San Antonio, Texas area, which is mainly composed of SFDHs. In [12] Gomez et al. calculated energy baselines, using site and source energy index (EI), for approximately 348,000 SFDHs in San Antonio to facilitate adoption of energy efficiency programs offered by the local utility. The authors categorized the homes into four distinct energy index categories, indicating that energy efficiency programs for newer, larger houses should be behavioral or educational in nature while programs for older houses should target the building envelope (e.g., building materials, insulation, windows, roof, foundation) and home systems (e.g., central heating, ventilation, and airconditioning, domestic water heating, and large appliances). In another study [13], the authors evaluated the influence of fireplaces on winter energy consumption in San Antonio, Texas. The results indicated that there is a significant $31 \%$ increase in energy use in homes with fireplaces. Moreover, in another study evaluating the impact of the presence of swimming pools on household electric intensity in San Antonio, Texas [14], the results suggested that on average, San Antonio homes with pools used over $40 \%$ more energy than comparable homes without pools. In a related study by a different author [15], statistical analysis indicated that among the urban form factors used, 
number of shared walls was the most important factor affecting the delivered energy use.

In this study, the authors characterize the SFAHs housing stock of Bexar County and evaluate the impact of key features commonly found in homes in the area (swimming pools, fireplaces) on household energy consumption. This study ascertains that the construction of housing alternatives, such as SFAHs, should be encouraged because of their relatively smaller footprint and increased potential for realizing significant energy savings due to shared walls and floors.

\section{Description of Dataset and Methodology}

According to the US Census-American Community Survey 5-year estimates, there are about 17,159 SFAHs in Bexar County built as of 2014 [16]. This study is based on an available dataset including information for 5565 SFAHs, equivalent to about $32.6 \%$ of all SFAHs. Energy information at the individual household level for the remaining 67\% of SFAHs is not available. Furthermore, a large number of SFAHs are located in and around military installations across the county; therefore, the data required to perform the analysis is not readily available. Pairing building data with utility energy data at the individual building level resulted in 3932 records with at least 12 consecutive months of energy consumption and necessary building characteristics. Therefore, analyses conducted and presented in this manuscript represent approximately $23.0 \%$ of the SFAHs within Bexar County, Texas.

Researchers were able to obtain complete building information for an additional 3252 SFAH records. Together, the resulting total is now 7184 SFAH, equivalent to approximately $42.0 \%$ of the entire SFAH housing stock. The physical characteristics of the homes within the subset of 3252 SFAHs are very similar to the characteristics of homes analyzed for this study. The average vintage is 1983; average size is $1350 \mathrm{sf}\left(125.42 \mathrm{~m}^{2}\right)$; homes are mostly 1-story; very few homes have a swimming pool or spa; and, about $58 \%$ of the homes have a fireplace.

For analysis, the data is further segmented by fuel type. Of the 3932 homes in this study, 1321 are all-electric (33.6\%) and 2611 are dual-fuel (66.4\%). All-electric homes have only access to electricity while dual-fuel homes have access to electricity and natural gas to satisfy the various end uses of energy within the home. Segmentation using other factors to include vintage and size, number of shared walls, number of stories, and reference versus non-reference homes is also part of this study. The objective of the segmentation approach is to compare energy consumption patterns within similar homes including additional segmentation of the stock based on key features of the home such as presence of swimming pools, fireplaces, number of stories, fuel type, area of conditioned space, and vintage. The analyses in this study are based on the fuel type of the home using source energy as the performance metric, as source energy captures the whole aspects of energy efficiency.

Key performance indicators such as annual and seasonal energy consumption are calculated to perform baseline and comparative type of analyses. The vintage and size 
segmentation methodology is based on categories as described by Gomez et al. [12] resulting in 64 unique subgroups. Vintage groups are determined to cover each decade from the 1950s to the present decade. Size categories are established based on 500square foot $\left(46.45 \mathrm{~m}^{2}\right)$ increments starting at less than $999 \mathrm{sf}\left(92.81 \mathrm{~m}^{2}\right)$ to larger than $4000 \mathrm{sf}\left(371.61 \mathrm{~m}^{2}\right)$.

Monthly energy consumption (both electricity and natural gas) for 2013 was estimated from utility billing information. Comparisons were made across the various SFAH sub groups. For the purposes of this study a constant temperature is assumed across the entire county. Historical weather data was obtained from weather underground [17] for the San Antonio International Airport weather station. Based on the weather data for San Antonio to disaggregate energy consumption between various end uses, the utilized energy through the year is divided into two main groups: weather sensitive (cooling for summer and heating for winter) versus non-weather sensitive (baseload, the minimum amount of energy necessary to operate the home year around). Heating months are January, February and December, representing winter energy consumption. Cooling months are May, June, July, August and September, representing summer energy consumption.

Reference homes were defined as homes that have no swimming pools, no hot tubs, no fireplaces, no solar photovoltaic (PV) ownership, have not participated in utility rebates, and are not certified under the Build San Antonio Green (BSAG) program. Nine parameters are identified for each of the 3932 homes as part of the analyses performed.

- Electric Consumption of 12 months for 2013,

- Gas Consumption of 12 months for 2013,

- Vintage [Year Built],

- Home Size [Living Area],

- Type of Fuel [Dual/Electric Only],

- Number of Shared-Walls [1/2],

- Number of Stories [1/2],

- Presence of Fireplace [Yes/No],

- Presence of Swimming Pool [Yes/No].

Therefore, source energy for every building is calculated based on Equation (1) in 1000 British Thermal Units (kBtu) and Equation (2) in kilowatt hours (kWh), below, to better understand utilization patterns regardless of the fuel utilized by the home. The concept of source energy helped to trace back the heat and electricity requirements to the raw fuel input. Therefore, the losses that usually occur during production, transmission and delivery of the energy to the site are considered in the source energy calculation. A five-year US average ratio is used to convert site to source energy. The ratio for grid electricity is 3.14 and for natural gas is 1.05 [18]. Values presented throughout the paper are in terms of source energy, unless otherwise specified.

Energy use intensity, often referred to as energy index (EI), is calculated based on site energy to compare homes across vintage and size categories. It is based on energy per area of conditioned floor space in $\mathrm{kBtu} / \mathrm{sf}$ Equation (3) and in $\mathrm{kWh} / \mathrm{m}^{2}$ Equation (4). 
Source Energy $(\mathrm{kBtu})$

$=($ Annual Electricity $(\mathrm{kBtu}) \times 3.14)+($ Annual Gas $(\mathrm{kBtu}) \times 1.05)$

Source Energy $(\mathrm{kWh})$

$=$ Source Energy $(\mathrm{kBtu}) \times(1000 \mathrm{Btu} / 1 \mathrm{kBtu}) \times(1 \mathrm{kWh} / 3413 \mathrm{Btu})$

Site Energy Index $(\mathrm{kBtu} / \mathrm{sf})$

$=($ Annual Electricity $(\mathrm{kBtu})+$ Annual Gas $(\mathrm{kBtu})) /$ Area of Conditioned Space $(\mathrm{sf})$

Site Energy Index $\left(\mathrm{kWh} / \mathrm{m}^{2}\right)=$ Energy Index $(\mathrm{kBtu} / \mathrm{sf}) \times(1,000 \mathrm{Btu} / 1 \mathrm{kBtu})$

$$
\times(1 \mathrm{kWh} / 3,413 \mathrm{Btu}) \times\left(10.7639 \mathrm{sf} / 1 \mathrm{~m}^{2}\right)
$$

\section{Results \& Discussion}

The homes studied were analyzed with respect to their fuel type (all-electric and dualfuel) across various other factors to include vintage and size, number of shared walls, number of stories, reference, and non-reference homes. The objective of the segmentation approach, as previously stated, is to compare similar homes as well as to compare energy consumption resulting from the presence of specific home features.

In terms of fuel-type, $66 \%$ of SFAHs are dual-fuel homes and $34 \%$ are all-electric homes with an average size of $1509 \mathrm{sf}\left(140 \mathrm{~m}^{2}\right)$ and $1376 \mathrm{sf}\left(128 \mathrm{~m}^{2}\right)$, respectively. Previous work from [12] on Bexar County's SFDH stock has shown that all-electric houses, on average, are newer and larger in size with lower site and source energy index values than those with access to natural gas. However, Table 1 indicates that all-electric SFAHs are newer with lower average source energy consumption and average site energy index compared to dual-fuel homes that are older (1978) and larger in size.

\subsection{Size and Vintage}

The average size for all SFAHs in this study is $1465 \mathrm{sf}\left(136 \mathrm{~m}^{2}\right)$. The average size of SFAHs in the resulting subset under analysis has not changed significantly over time. Homes built in the 1960s, are larger in size compared to homes in all other decades and homes built in the 1980s have the smallest average size (Figure 1). Since the 1990s the average size of homes has stayed relatively constant and just above the building stock's average. In terms of vintage, the majority of SFAHs are built in the 1970s and 1980s (76\%) followed by 1990s and 2010-present (23\%). Since 2000, there are more reference homes built than non-reference homes. Larger homes ( $>2500 \mathrm{sf}$ in size $\left[>232.3 \mathrm{~m}^{2}\right]$ )

Table 1. Average energy consumption of homes based on fuel type.

\begin{tabular}{cccc}
\hline Category & Average Vintage & $\begin{array}{c}2013 \text { Source Energy kBtu } \\
(\mathrm{kWh})\end{array}$ & $\begin{array}{c}\text { Average Site Energy Index kBtu/sf } \\
\left(\mathrm{kWh} / \mathrm{m}^{2}\right)\end{array}$ \\
\hline All Homes & 1983 & $145,532(42,640)$ & $41.5(131.4)$ \\
All-electric & 1994 & $139,097(40,755)$ & $33.9(101.7)$ \\
Dual-Fuel & 1978 & $148,787(43,594)$ & $45.4(143.4)$ \\
\hline
\end{tabular}




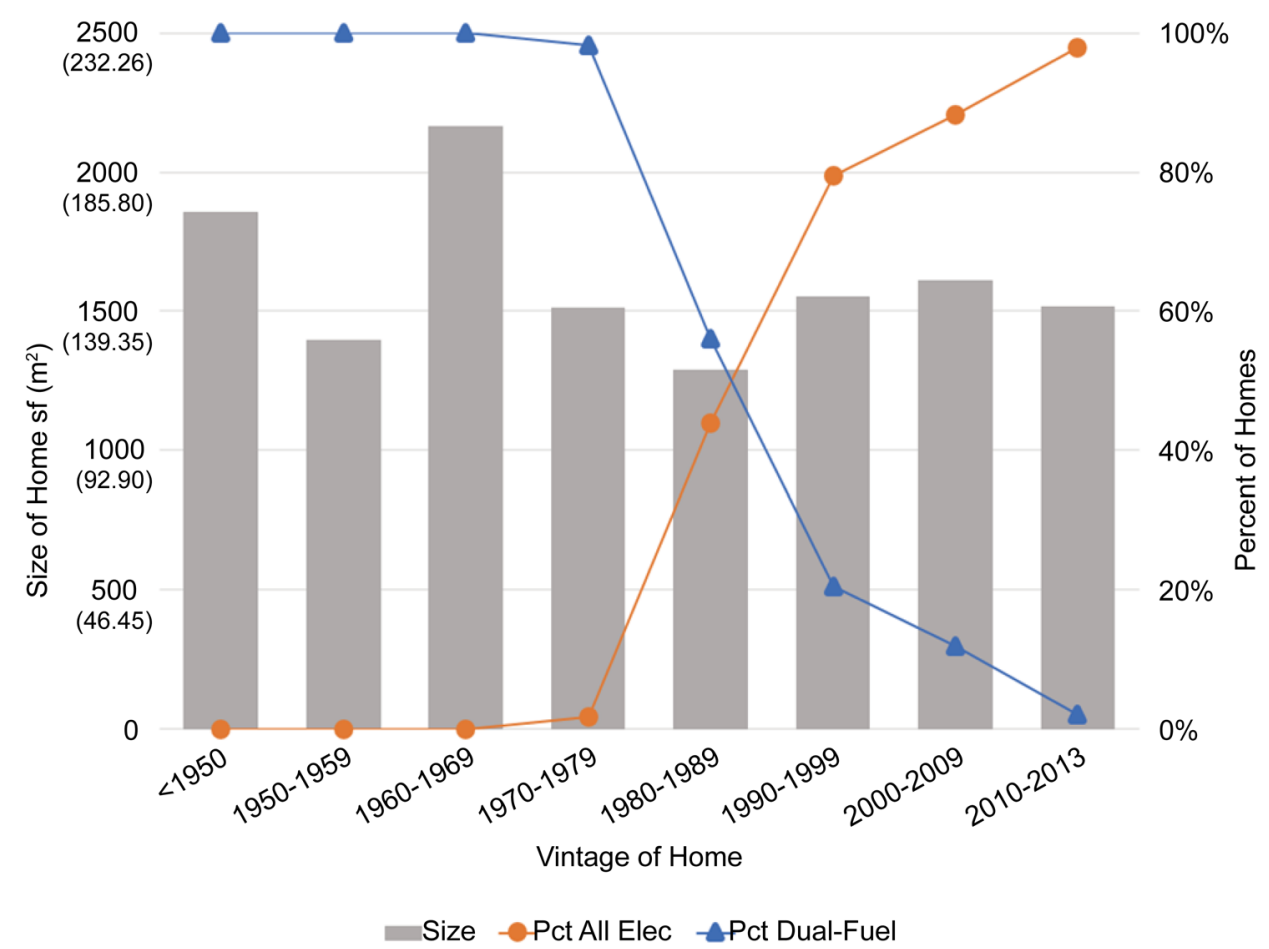

Figure 1. Percent of homes by fuel type based on size and vintage.

are more likely to have fireplaces, swimming pools or both features. Before the 1980s, 98\% percent of homes are dual-fuel homes. However, since the 1980s more all-electric homes have been built and the number of dual-fuel homes has experienced a steep decrease, as shown in Figure 1. There are a couple of main reasons for the steep increase in the number of all-electric homes built since the 1980s: 1) the local geology, and, 2) incentives by the local utility. The geology influences development and construction decisions because the soils in the area soils are such that digging and trenching required for installation of natural gas lines is difficult and costly. Local developers and home builders opted to build more all-electric homes, which have lower utility connection and site development costs compared to dual-fuel homes. Cost of mechanical systems is also different for all-electric homes and dual-fuel homes (gas water heaters, gas furnaces, etc). The local electric utility does not control access to natural gas for the entire area within Bexar County. As a consequence, the utility cannot provide natural gas to all of the customers for which it already provides electricity. The resulting effect is a net increase in the number of all-electric homes built in the area.

\subsection{Reference vs Non-Reference Homes}

In general, reference SFAHs in the San Antonio area tend to be smaller in size than non-reference homes with an average size of $1311 \mathrm{sf}\left(122 \mathrm{~m}^{2}\right)$ and built in the 1980s. Figure 2 shows the source energy for reference homes and non-reference homes in 2013. Residential energy consumption per unit of conditioned space, also referred to as energy index, is $9.5 \%$ lower for reference homes compared to non-reference homes. 


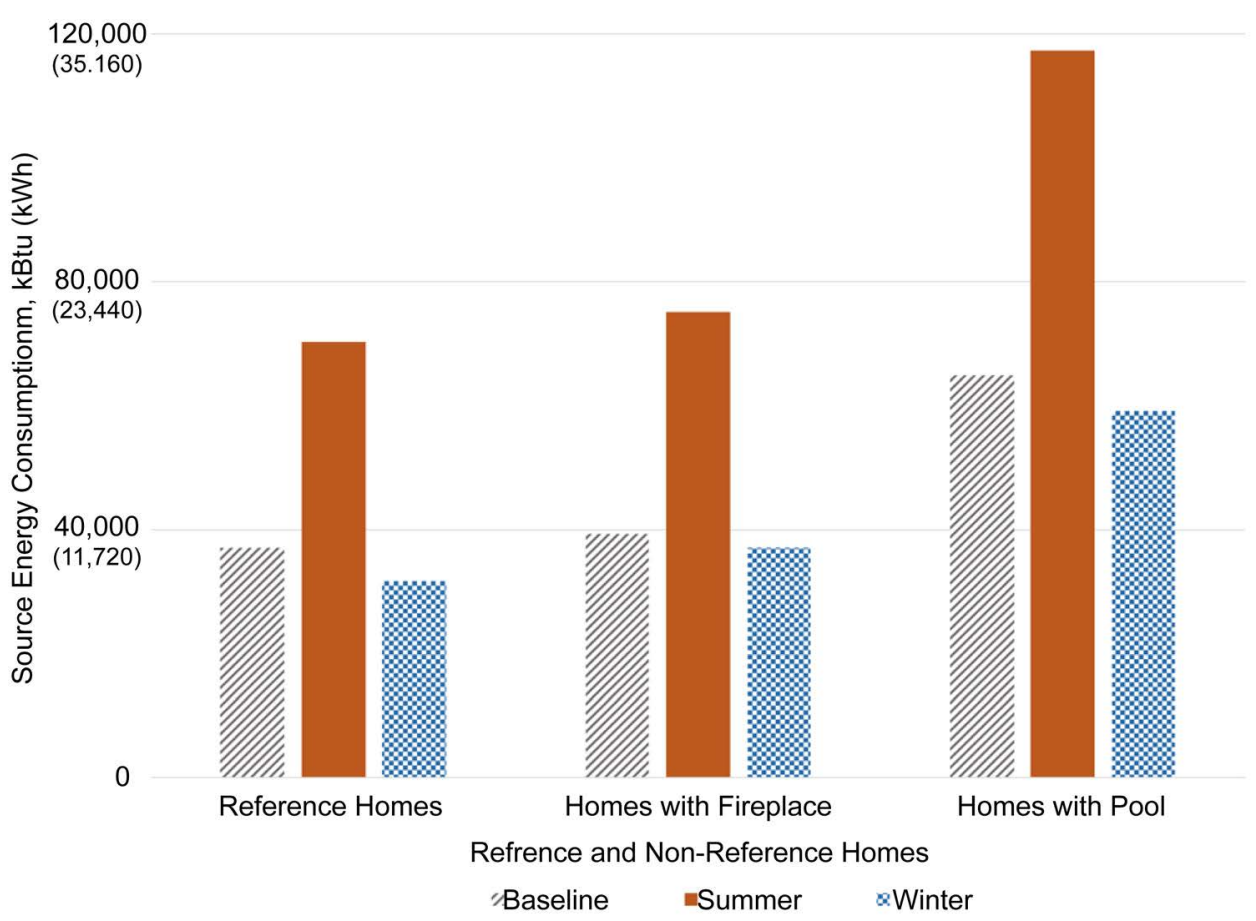

Figure 2. Average Source energy of reference homes vs non-reference homes.

The non-reference homes are bigger in size and therefore consume more energy compared to reference homes [19].

In terms of source energy reference homes consume significantly $(9.2 \%)$ less energy compared to non-reference homes ( $\mathrm{p}$-value $<0.05, \mathrm{df}=3855$ ) and are mostly built in the 1970s and 1980s. There is also a significant difference ( $\mathrm{p}$-value $<0.05, \mathrm{df}=3848$ ) in the baseload source energy consumption of reference homes when compared to nonreference homes. In addition, non-reference homes include homes with fireplaces and/or swimming pools, which have been shown to increase seasonal energy consumption.

The homes with a pool and/or spa, consume significantly (47.9\%) more source energy in the summer on average $13,279 \mathrm{kBtu}(3892 \mathrm{kWh})$ compared to homes without pools and/or spas ( $\mathrm{p}$-value $<0.05, \mathrm{df}=77$ ). Additionally, the impact of the presence of fireplaces on winter source energy consumption of homes was also studied. Homes with fireplaces, consume significantly (15.4\%) more source energy in winter by the average of $5304 \mathrm{kBtu}(1554 \mathrm{kWh}$ ) compared to homes without fireplaces (p-value $<0.05$, $\mathrm{df}=3735)$. Results from this study are aligned with previously published work by the authors studying the impact of fireplaces on energy consumption in SFDHs [13] that indicated homes with fireplaces consume approximately $31 \%$ more heating energy than homes without fireplaces, regardless of fuel type.

As shown in Figure 2, homes with pools consume on average $74 \%$ more energy in all seasons than reference homes. It can be said, there is a positive correlation between swimming pool presence and overall household energy consumption. The presence of pool is also the indicator of other household structural, behavioral, and demographical 
features that are associated with higher energy consumption. Compared to reference homes, homes with fireplaces consume more energy in the winter. Based on our dataset, homes with swimming pools consume, on average, $67 \%$ more energy during the summer months when compared to reference homes. Similarly, homes with fireplaces consume, on average, $17.2 \%$ more energy during winter months compared to reference homes. Results from this study are aligned with previously published work by the authors studying the impact of swimming pools on household electric intensity in San Antonio, Texas [14] that indicated homes with pools used over $40 \%$ more energy than comparable homes without pools.

All-electric homes consume $6.7 \%$ less source energy compared to dual-fuel homes ( $\mathrm{p}$-value $<0.05, \mathrm{df}=3156$ ). In Figure 3 the average winter source energy of homes with fireplaces is studied. Results indicate that winter source energy consumption for reference dual-fuel homes is less than dual-fuel homes with fireplaces by $18 \%$. The average vintage of dual-fuel reference homes and dual-fuel homes with fireplaces is approximately the same (1978); however, dual-fuel homes with fireplaces are approximately $420 \mathrm{sf}\left(39 \mathrm{~m}^{2}\right)$ larger than dual-fuel reference homes.

Reference all-electric homes consume $9 \%$ less winter source energy compared to allelectric homes with fireplaces. The average size of all-electric reference homes and allelectric homes with fireplaces is approximately the same; however, all-electric homes with fireplaces are 12 years older (1988) on average than reference homes (2000).

\subsection{Number of Shared Walls}

By definition, SFAHs share one or two walls, a factor that affects energy consumption.

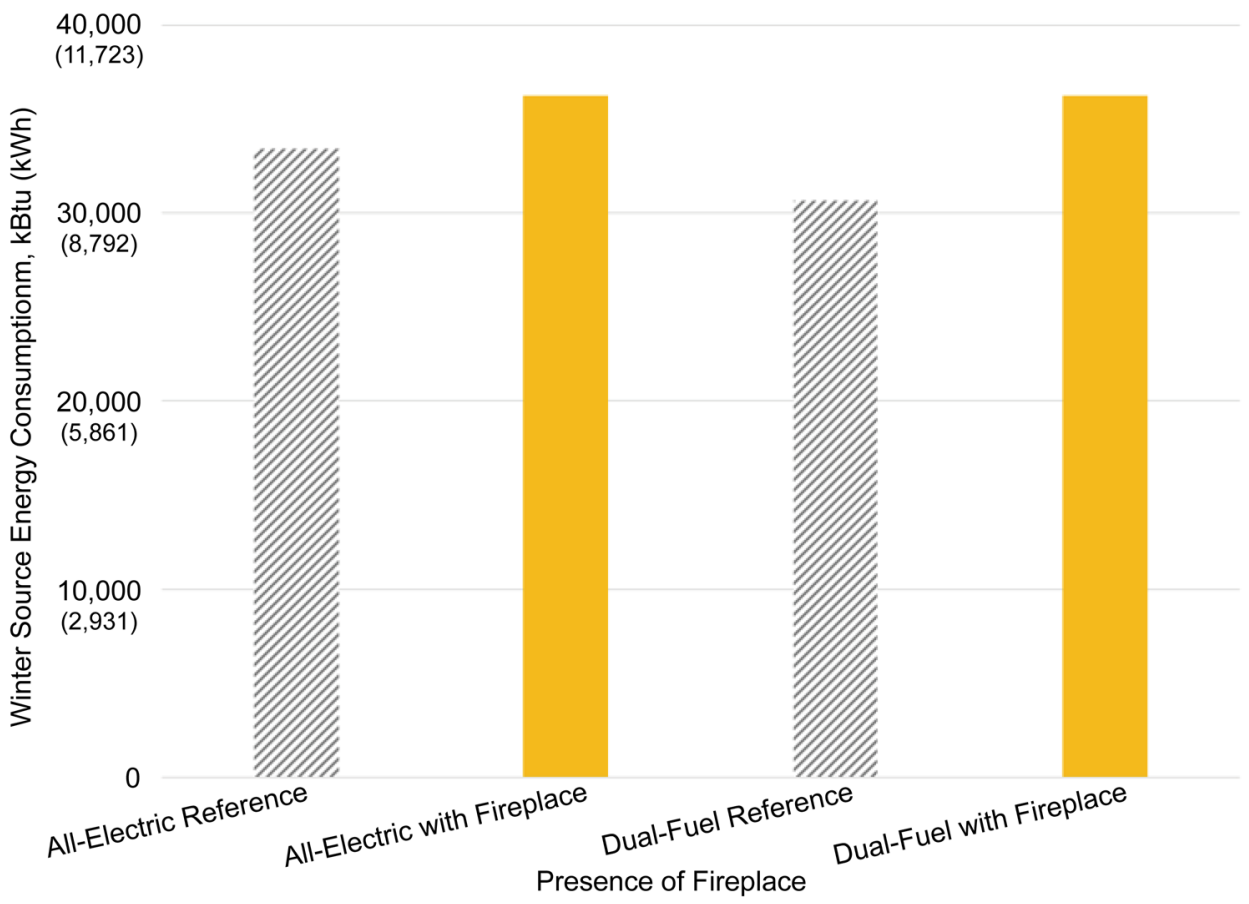

Figure 3. 2013 source energy consumption for homes with fireplaces by fuel type. 
In the data set, 169 records out of 3932 homes did not have data on the number of shared walls and are therefore excluded from further analysis. 58\% of the SFAHs share one wall and the rest (42\%) share two walls. Table 2 indicates the source energy consumption in one- and two-walls shared all-electric and dual-fuel homes. The number of homes with one-shared wall in both all-electric and dual-fuel categories is higher than the number of homes with two-shared walls. The all-electric homes with two-shared walls consume significantly $(6.85 \%)$ ( $\mathrm{p}$-value $<0.05, \mathrm{df}=576$ ) less energy than homes sharing one wall. However, the source energy consumption of dual-fuel homes with one- or two-shared walls is not significantly different ( $\mathrm{p}$-value $>0.05, \mathrm{df}=2511$ ). This result is aligned with previous related studies on the effects of household and building characteristics on the annual energy consumption of US residential buildings by [10] [15] [20] and [21].

Within both fuel type categories, homes with one-shared wall are smaller in size and consume more energy compared to homes with two-shared walls. Sharing more than one wall will help to minimize the surface of the building that is exposed to outside temperature and conditions. The results indicate that the number of shared walls is a factor on the energy consumption of the homes, due to the reduction in exposure to sun, wind, and other climatic features.

\subsection{Number of Stories}

The results from a study [22] on the urban energy consumption at neighborhood scale support the results of this study. Researchers indicated that the most effective urban factor besides other physical factors such as parcel size and setback on energy consumption is the number of floors or stories (building height).

The number of stories of a home, which is an indicator of the exposed surface area of the home, is considered to have an effect on the energy consumption of the building. In a study on efficient design of residential buildings [23], results indicated that a smaller façade resulted in $26.67 \%$ reduction in energy consumption.

As illustrated in Figure 4, energy consumption of all-electric and dual-fuel homes is analyzed based on number of stories and size. Two-story dual-fuel homes sized 1000 $1499 \mathrm{sf}\left(93-139 \mathrm{~m}^{2}\right)$ [size category 2] and two-story all-electric homes sized 1500 -

Table 2. Source energy consumption in homes with one and two-shared walls.

\begin{tabular}{lcccc}
\hline & \multicolumn{2}{c}{ All-Electric Homes } & \multicolumn{2}{c}{ Dual-Fuel Homes } \\
\cline { 2 - 5 } & One-shared wall & Two-shared wall & One-shared wall & Two-shared wall \\
\hline Average Vintage & 1993 & 1997 & 1979 & 1979 \\
Average Size sf $\left(\mathrm{m}^{2}\right)$ & $1309(122)$ & $1558(145)$ & $1455(135)$ & $1566(145)$ \\
$\begin{array}{l}\text { Source Energy } \\
\text { Consumption kBtu }(\mathrm{kWh})\end{array}$ & $141,604(41,490)$ & $132,526(38,830)$ & $150,386(44,063)$ & $147,199(43,129)$ \\
$\begin{array}{l}\text { Average Site Energy Index } \\
\mathrm{kBtu} / \mathrm{sf}\left(\mathrm{kWh} / \mathrm{m}^{2}\right)\end{array}$ & $36.3(114.8)$ & $27.7(87.9)$ & $47.2(149.6)$ & $43.3(137)$ \\
\hline
\end{tabular}


160,000

$(46,880)$

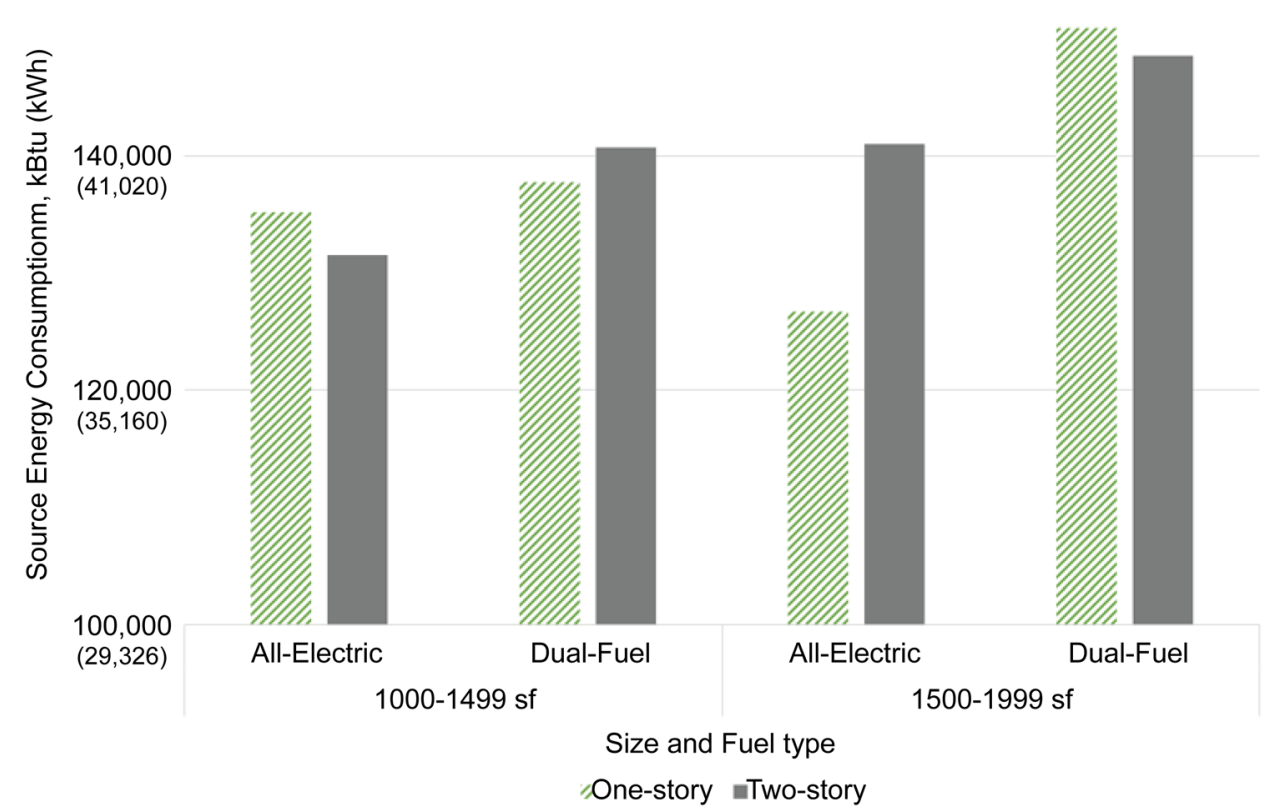

Figure 4. Average source energy consumption of all-electric and dual-fuel homes based on number of stories and size.

$1999 \mathrm{sf}\left(139-186 \mathrm{~m}^{2}\right)$ [size category 3] consume more energy than the one-story counterparts.

The two-story all-electric homes sized 1500 - $1999 \mathrm{sf}\left(139-186 \mathrm{~m}^{2}\right)$ [size category 3] consume $11.34 \%$ ( $\mathrm{p}$-value $<0.05, \mathrm{df}=85$ ) more energy throughout the year compared to one-story homes. The reason is further investigated, and it appeared that average vintage of homes is similar and both one-story and two-story homes do not have swimming pools. However, the 2-story homes have greater number of fireplaces and more are sharing two-walls. That said, neither of these factors adequately explains the $11.34 \%$ increase in source energy consumption.

On the other hand, although two-story dual-fuel homes sized 1000 - 1499 sf (93 - 139 $\mathrm{m}^{2}$ ) [size category 2], consume $2.15 \%$ more energy throughout the year compared to one-story homes, the difference in source energy consumption is not significant ( $\mathrm{p}$-value $>0.05, \mathrm{df}=213$ ).

Interestingly, an insignificant decrease $(2.80 \%)$ is seen in source energy consumption ( $\mathrm{p}$-value $>0.05, \mathrm{df}=669$ ) from one- to two-story homes when looking at all-electric homes sized $1000-1499 \mathrm{sf}\left(93-139 \mathrm{~m}^{2}\right)$ [size category 2]. Within this size category there is a larger presence of fireplaces and two shared-walls in one-story homes compared to two-story homes.

In addition, an insignificant decrease (1.58\%) is seen in source energy consumption ( $\mathrm{p}$-value $>0.05, \mathrm{df}=919)$ from one- to two-story homes when looking at dual-fuel homes sized 1500 - $1999 \mathrm{sf}\left(139-186 \mathrm{~m}^{2}\right)$ [size category 3]. Within this size category there is a larger presence of pools in one-story homes compared to two-story homes. 


\section{Conclusions and Policy Implications}

This study investigated source energy consumption for approximately 33\% of SFAHs in Bexar County, Texas. The objective of this study was to better understand the stock of SFAHs and associated energy utilization patterns. A secondary objective was to identify potential implications of current building practices and promote development of more energy-efficient housing alternatives. Results indicate that the size of SFAHs has been relatively stable over time. The homes are relatively efficient, with an average energy index of less than $50 \mathrm{kBtu} / \mathrm{sf}\left(157.5 \mathrm{kWh} / \mathrm{m}^{2}\right)$. Reference SFAHs in the area are smaller in size (average size of $1311 \mathrm{sf}\left[122 \mathrm{~m}^{2}\right]$ ), were built in the 1980s, and consume less energy compared to non-reference SFAHs. Newer single-family attached homes tend to consume less energy on an annual basis and have lower energy index values.

The study shows that home size is the driving factor in energy consumption. Smaller homes with pool and/or spa or fireplace consume more energy than larger homes, which have none of the mentioned features. Therefore, as shown in Figure 5, the major drivers of energy consumption for SFAHs in the area are: 1) home size or area of conditioned space, 2) presence of swimming pools, 3) number of bedrooms, 4) number of stories, 5) presence of fireplace, 6) home vintage, 7) fuel-type, and 8) lot size.

The results of this study also show that in terms of energy consumption, all-electric two-story homes that are sharing two walls are the most energy efficient among SFAHs. Therefore, to promote energy-efficient housing alternatives, it would be helpful to build smaller reference SFAHs. Finally, the researchers recommend further investigation using modelling programs and experimental methods to highlight the effect of housing

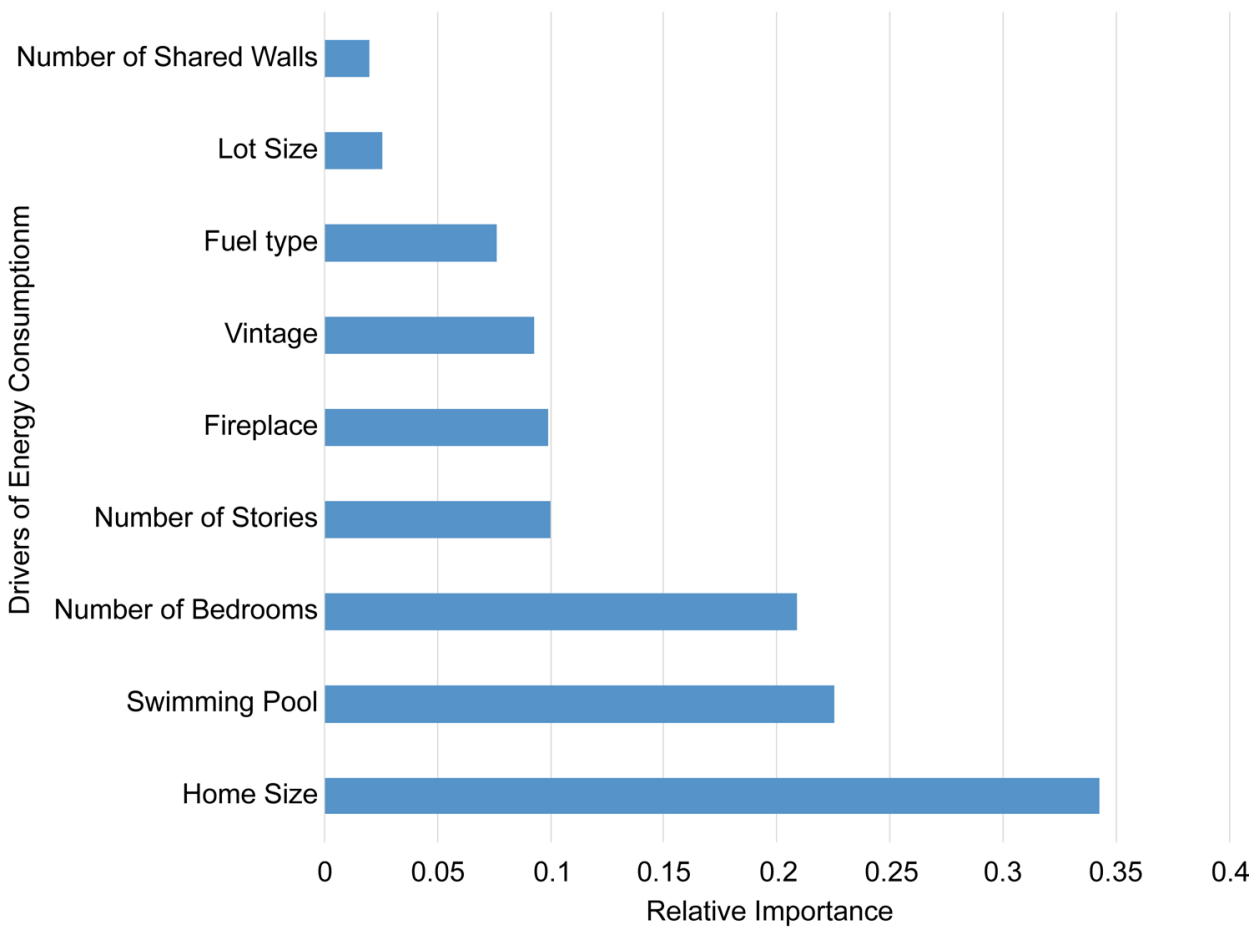

Figure 5. Drivers of energy consumption in single family attached homes. 
characteristics on energy consumption considering more detailed climatic conditions, and to implement the findings as part of a housing strategy that promotes energy efficiency in building design and long-term urban planning.

\section{Acknowledgements}

This project and the preparation of this manuscript were funded in part by monies provided by CPS Energy through an Agreement with the University of Texas at San Antonio. Special thanks to research students Rohith Polishetty, Rahul Nair, and Vidal Ramirez.

\section{References}

[1] Pitt, D. (2013) Assessing Energy Use and Greenhouse Gas Emission Savings from Compact Housing: A Small-Town Case Study. Local Environment, 18, 904-920.

[2] Ewing, R. and Fang, R. (2008) The Impact of Urban Form on U.S. Residential Energy Use. Housing Policy Debate (Metropolitan Institute at Virginia Tech), 19.

[3] Friedman, A. (2013) Circulation and Open Space in Affordable Townhouse Communities. Open House International, 38, 6-15.

[4] McKenzie, E. (2003) Common-Interest Housing in the Communities of Tomorrow. Housing Policy Debate, 14, 203-234.

[5] Zoeller, W., Slattery, M. and Grab, J. (2013) Fort Devens: Cold Climate, Energy Efficient, Market-Rated Townhomes. The National Renewable Energy Laboratory, Denver.

[6] Asfour, O.S. and Ebtesam, S.A. (2015) Effect of Housing Density on Energy Efficiency of Buildings Located in Hot Climates. Energy and Buildings, 91, 131-138.

[7] Philipsen, K., FAIA (2014) The Energy Footprint of Apartments. Rowhouses and Houses, $1-9$.

http://archplanbaltimore.blogspot.com/2014/01/the-energy-footprint-of-apartments.html

[8] (2015) State \& County QuickFacts. http://quickfacts.census.gov/qfd/states/48/4865000.html

[9] Lee, S. and Lee, B. (2014) The Influence of Urban Form on GHG Emissions in the U.S. Household Sector. Energy Policy, 68, 534-549.

[10] Kaza, N. (2010) Understanding the Spectrum of Residential Energy Consumption: A Quantile Regression Approach. Energy Policy, 38, 6574-6585.

[11] Valenzuela, C., Valencia, A., White, S., Jordan, J.A., Cano, S., Keating, J. and Potter, L.B. (2014) An Analysis of Monthly Household Energy Consumption among Single-Family Residences in Texas, 2010. Energy Policy, 69, 263-272.

https://doi.org/10.1016/j.enpol.2013.12.009

[12] Gomez, J.D., Elnakat, A., Wright, M. and Keener, J. (2014) Analysis of the Energy Index as a Benchmarking Indicator of Potential Energy Savings in the San Antonio, Texas Single-Family Residential Sector. Energy Efficiency, 8, 577-593.

https://doi.org/10.1007/s12053-014-9310-6

[13] Elnakat, A. and Gomez, J.D. (2016) The Flame Dilemma: A Data Analytics Study of Fireplace Influence on Winter Energy Consumption at the Residential Household Level. Energy Reports, 2, 14-20. https://doi.org/10.1016/j.egyr.2016.01.002

[14] Elnakat, A., Gomez, J.D., Roberts, J. and Wrigth, M. (2015) Big Data Analysis of Swimming Pools' Impact on Household Electric Intensity in San Antonio, Texas. International Journal 
of Big Data Intelligence, 2, 250-261. https://doi.org/10.1504/IJBDI.2015.072162

[15] Perkins, A. (2003) The Significance of Urban Form in Creating More Greenhouse-Friendly Cities. National Planning Congress: Leading with Diversity, Adelaide.

[16] US Census Bureau, 2010-2014 American Community Survey 5-Year Estimates. 2014. Census of Housing. http://factfinder.census.gov/faces/tableservices/jsf/pages/productview.xhtml?src=bkmk

[17] Weather Forecast \& Reports (2016). https://www.wunderground.com/?MR=1

[18] Energy Star (2013) Source Energy Portfolio Manager.

[19] Majcen, D., Itard, L. and Visscher, H. (2013) Actual and Theoretical Gas Consumption in Dutch Dwellings: What Causes the Differences? Energy Policy, 61, 460-471. https://doi.org/10.1016/j.enpol.2013.06.018

[20] Estiri, H. (2014) Building and Household X-Factors and Energy Consumption at the Residential Sector: A Structural Equation Analysis of the Effects of Household and Building Characteristics on the Annual Energy Consumption of US Residential Buildings. Energy Economics, 43, 178-184. https://doi.org/10.1016/j.eneco.2014.02.013

[21] Samuelsona, H., Claussnitzerb, S., Goyal, A., Chena, Y. and Romo-Castilloa, A. (2016) Parametric Energy Simulation in Early Design: High-Rise Residential Buildings in Urban Contexts. Building and Environment, 101, 19-31. https://doi.org/10.1016/j.buildenv.2016.02.018

[22] Soltani, A., Mehraein, M. and Sharifi, S. (2012) Urban Features and Energy Consumption at Local Level. Journal of Urban and Environmental Engineering, 6, 43-47. https://doi.org/10.4090/juee.2012.v6n2.043047

[23] Pacheco-torres, R., López-alonso, M., Martínez, G. and Ordóñez, J. (2015) Efficient Design of Residential Buildings Geometry to Optimize Photovoltaic Energy Generation and Energy Demand in a Warm Mediterranean Climate. Energy Efficiency, 8, 65. https://doi.org/10.1007/s12053-014-9275-5

Submit or recommend next manuscript to SCIRP and we will provide best service for you:

Accepting pre-submission inquiries through Email, Facebook, LinkedIn, Twitter, etc. A wide selection of journals (inclusive of 9 subjects, more than 200 journals)

Providing 24-hour high-quality service

User-friendly online submission system

Fair and swift peer-review system

Efficient typesetting and proofreading procedure

Display of the result of downloads and visits, as well as the number of cited articles Maximum dissemination of your research work

Submit your manuscript at: http://papersubmission.scirp.org/

Or contact ojee@scirp.org 